\title{
ISLAMIC VALUES BEHIND THE RITUAL OF A COW HEAD BURIAL IN GREBEG SURO
}

\author{
Penny Respati Yurisa', Rikg Fu'aturosida', Yusuf Ratu Agung ${ }^{1}$, \\ and Ulfah Muhayani \\ ${ }^{1}$ Universitas Islam Negeri Maulana Malik Ibrahim Malang, Indonesia \\ ${ }^{2}$ Queensland University of Technology, Australia \\ Email: penny@bsa.uin-malang.ac.id
}

Received: October 31, 2020

Accepted: June 4, 2021

\section{Abstract}

This paper aims to uncover the Islamic values behind the ritual of a cow head burial held by people in Bamboo Forest, Sumbermujur, Candipuro, Lumajang. It is one of the rituals of a popular Javanese culture called Grebek Suro, conducted in the first month of the Javanese calendar. It finds that the Islamic value of the ritual is salam or safety. The cow head burial is intended to bring about safety (slamet) towards society in the upcoming year. This research is expected to contribute in calling people for preserving local culture and Islamic values within the rituals. It is limited to the exploration of the Islamic values within the ritual of a cow head burial in Grebeg Suro ceremony. Further researches are expected to study the other rituals, such as Gunungan, Tumpengan, Japa Mantra, Larungan, and the dancing ritual.

Tulisan ini bertujuan untuk mengungkap nilai Islam di balik ritual penanaman kepala sapi yang dilakukan oleh masyarakat di Hutan Bambu, Sumbermujur, Candipuro, Lumajang. Ini adalah salah satu ritual budaya Jawa terkenal, Grebek Suro, yang dilakukan pada bulan pertama penanggalan Jawa. Studi ini menemukain bahwa nilai Islam dari ritual tersebut adalah salam atau keselamatan. Penguburan kepala sapi dimaksudkan untuk membawa keselamatan 
(slamet) bagi masyarakat di tahun mendatang. Penelitian ini diharapkan dapat berkontribusi dalam mengajak masyarakat untuk melestarikan budaya lokal dan nilai-nilai Islam dalam ritualnya. Penelitian ini terbatas pada penggalian nilai-nilai Islam dalam ritual penguburan kepala sapi di upacara Grebeg Suro. Penelitian selanjutnya diharapkan menganalisis ritual-ritual lainnya, seperti Gunungan, Tumpengan, Japa Mantra, Larungan, dan ritual menari.

\section{Keywords: Islamic Vvalues; Grebeg Suro; Rritual}

\section{Introduction}

Suro is the name of the first month of twelve months in Saka Jawa, the Javanese calendar. The calendar has a cycle of eight years. The original calendar in Java was initially based on the solar year. However, the date calculation system was changed centuries ago by a Javanese king to follow the Islamic system, based on the lunar system. For Javanese who are known to be deeply superstitious, Suro is sacred. Many communities believe supernatural forces roam around at night on the 1st of Suro, so they do not leave home except for praying or performing spiritual rituals. However, in other places in Java, the 1st of Suro is a night of celebration. In Yogyakarta for example, on the first day of Suro, thousands of people come out to walk in silence around sacred fort. This procession is known as "tapa bisu mubeng benteng". People believe it as a ritual of cleaning soul and praying for a better year. Not far from Yogyakarta, a few hours to the north, in Solo, the sultan organizes a cultural parade called "kirab pusaka" or carnival heritage (Siburian \& Malau, 2018).

Suro is also known as Muharram for Muslims. Muharram is the first month of Islamic calendar. The first month, Muharram, is one of the four sacred months of the year for Muslims besides Rajab, Dzulhijah, Dhulqoidah, and Ramadan. During these sacred months, warfare is forbidden. Muharram is considered to be highly religious. Muharram means "forbidden" since it is considered to be holy. Many Muslims use it as a period of prayer and reflection. It is common for people to fast during the holy Muharram. In an old time, there were several important events conducted in Muharram. Muharram also marks the anniversary of the battle of Karbala, where the Islamic prophet Muhammad's grandson, Imam Hussain Ibn Ali, was killed (Jalais, 2014).

For Javanese and Muslim community, Suro or Muharram is sacred and very important because it is believed to be the starting record for a new life stage for the following year. In comparison, Muharram is celebrated as the advent 
of the Islamic New Year by Muslims. For Muslim who live in Java, especially the central and East Java, Suro or Muharram is a month in which they do reflection for what they have done in the previous year and as a celebration of a new year as well as a prayer for safety, prosperity, and happiness in the coming year (Kurniawan, 2019).

Javanese Muslim community hold a very well-known ceremony in the month of Suro called Grebeg Suro. It is held in most cities and places in the Central and East Java, such as Ponorogo, Banyuwangi, and Lumajang (Hanif \& Zulianti, 2012). This ceremony is carried out to obtain safety while its implementation varies in each region.

In Lumajang, the ceremonial of Grebeg Suro is held in Bamboo Forest, Sumbermujur Village, Candipuro. Several rituals were held by villagers such as Gunungan, Tumpengan, burying a cow head, Japa Mantra (praying), Larungan, and dancing. This paper aims to discuss one of these rituals, cow head burial, because it is significant for the indigenous. The ritual is analyzed to understand the aspect of Islamic values within.

The rituals of Grebeg Suro ceremony in Lumajang are carried out in several sequences of activities, which are Gunungan, Tumpengan and Ingkung, a cow head burial, praying or Japa mantra, larung sajen, and dance oling. The first ritual to the last ritual are related to each other. All rituals are performed consecutively on the same day. It was attended by residents from seven hamlets in Sumbermujur village, elders, head of the village and village officials, the Head of the Police, and the Regent of Lumajang. For people in Lumajang, Grebeg Suro ritual is an expression of gratitude and salvation to God.

The first ritual in Grebeg Suro is called Gunungan, making mountains of crops by seven hamlets. They are made from banana leaf stems decorated with vegetables and fruits harvested by the villagers, then sticking them into banana leaf stalks using bamboo skewers and arranged into colorful mountains. They are placed on stretchers made of bamboo. The stretchers are given four handles to be lifted by four people. They are collected at the location of the Grebeg Suro ceremony along with other ritual equipment. Seven mountains of crops symbolize the charm of tourism that comes from the village. Grebeg, the Earth resource, symbolizes that everything taken from the nature also has universal rights, so the duck symbolizes the purification of fortune and sharing with the public. This procession is prepared in a cooperative manner using the available resources in Sumbermujur village.

el Harakah Jurnal Budaya Islam Vol. 23 No. 1 Tahun 2021 
The second ritual is Tumpengan and Ingkung. Seven hamlets in the village of Sumbermujur make tumpeng equipped with ingkung ayam and collect it with other ritual equipment around the ceremony site. Tumpeng is made from yellow rice shaped into a cone in a container called tempeh equipped with side dishes of fish, chicken, tofu, tempeh, eggs and cooked vegetables. Ingkung or whole cooked chicken also complements the existing tumpeng. The tumpeng are neatly arranged around the cow's head. Before being placed on the tempeh, the tumpeng is covered with green banana leaves. It is also decorated with tomatoes and green raw vegetables.

The third ritual is a cow head burial, which is done by preparing a cow head decorated with a small red and white flag. The cow head is placed facing the sky on a small stretcher at the size of the cow head. The stretcher is made of bamboo designed with a handle to be lifted by the stretcher carrier. There are four stretchers gathered with the tumpeng. The excavation of the hole is initiated symbolically by the Regent of Lumajang and the Chief of Police. The head of the village and several elders put the cow head into the hole and fill it with soil. In this ceremony, a cow head is buried in a bamboo forest. The bamboo forest is considered sacred by the people around Sumburmujur village.

Unlike Grebeg Suro ceremonies in other areas in Java, in this village, there are certain different rituals from those in other areas. One of them is a water spring. It is believed that when the offering ceremony is received, a giant eel will appear in the pool of the water source. There are no giant eels in that place. It shows that the ceremony in Sumbermujur village is different and unique compared to the Grebeg Suro ceremony in other areas.

The fourth ritual is reciting a prayer or Japa Mantra. After all the mountains of crops, tumpeng and cow head are gathered at the ceremony location, the Shaman leads the prayer (japa mantra). During the ceremony, the Shaman reads Islamic prayers mixed with Javanese, says basmalah, mentions Gusti Alloh, and closes with hamdalah. After reciting the mantra, the Shaman and hamlet head lead the burial of the cow head in a particular hole next to the sacred pavilion near the water source. Japa mantra is a string of prayers offered in two languages representing two cultures that have grown in Sumbermujur Village. Prayers in Javanese and blessings in Arabic. The mention of Gusti, Allah, or God is the labeling of humans within the limits of their knowledge, which leads to the same source, namely the Lord of the universe. The prayers use Arabic and Javanese mantras with the same purpose, asking for God's help and at the same time offering gratitude so that the next year can be good 
or better than the current year. The reality of God can be reached in various ways. Language is a cultural product, a derivative of God's creation. The accommodation process from the two different cultural backgrounds with the same purpose in the passage of the prayer/chanting mantra illustrates that the same prayer is in one reality of God, God Almighty.

The fifth ritual is a ceremony to make offerings into a pool of water sources and reciting a prayer while waiting for the release of a giant eel considered mysterious. When the giant eel comes out, they think that their prayer is accepted. The eel comes out after a few minutes of offering. Then, it goes to the water source and does not appear again-big-sized eels, bigger than eels in general. The eel is called Oling. The name Oling is used as the name of the dance in this Grebeg Suro ceremony.

The sixth ritual is Oling Dance, which is performed by dozens of dancers. Dancers are students who are members of a dance studio called Sekar Arum. The dance music begins with the lyrics Bismillahirrohmanirrohim heard very clearly, sung by a male singer. All dancers and the coaches wear a headscarf. During the ceremony, the dancers, who were originally veiled, did not wear the veil when performing. The music and dance movements of Oling are created by the performers and are carried out from generation to generation every Grebeg Suro, 1st Muharram ceremony.

The rituals of Grebeg Suro reflect the presence of acculturation. It is defined as a mixture of two or more cultures that meet and influence each other. It is a process of entering the influence of foreign culture in society. Some selectively adopt few or many elements of the foreign culture, and some try to resist these influences. When getting the influence of foreign culture in society, some selectively adopt few or many elements of the foreign culture, and some try to resist these influences (Berry, 2005). Thus, Islamic acculturation means the mixture of the Islamic values with local culture to the extent that, whether realized or not, the local culture appears as if it is a part of the Islamic teachings. It happens in many parts of Indonesia wherein a great number of Muslim populations reside.

The acculturation of Islamic values and local culture in Indonesia, especially in Java, can be traced back to how Islam was first introduced to people in Indonesia and how it was accepted by most people (Sumbulah, 2012). The onset of Islam in Indonesia has its unique history. Islam in Indonesia was not a local product. Islam was born in Arab, precisely in the region of Hijaz. According to some sources from Gujarat, India, Sufi traders brought 
the arrival of Islam to Indonesia during the $13^{\text {th }}$ century (Nurbaiti, 2020). By the end of $16^{\text {th }}$ century, Islam had surpassed Hinduism and Buddhism as the dominant religion of the peoples in Java and Sumatra.

The arrival of Islam in Indonesia changed the faith and the social structure of society. Hinduism, Buddhism, and other sects entered Indonesia long before Islam came to Indonesia. The Indonesian people are accustomed to carrying out cultural traditions and customs that are colored by these religions. However, due to the arrival of Islam, a social transformation process occurred in religious practices. To some extent, incoming culture would typically go through acculturations with the pre-existing culture, local ritual practices, and how a community accepted and adapted to a new way of life. An example of acculturation of Islam and Javanese culture well known to many people was slametan, which was later directed to Tahlilan in the era of Wali Songo, with the same concept, namely gathering, praying, and eating together (Lestari, 2011).

Furthermore, Islam was brought to different regions in Indonesia through peace missionary invitation, not war. Islam was introduced as a religion of peace. Islam was not against local culture and customs, yet it colored them. The way Islam was introduced to people made people of Nusantara willingly accept Islam. The societies even developed their methods to preserve the harmony between what they had as a way of life and what Islam offered them. They well understood that the cultures and traditions would continue to exist without offending the spirit of Islam, and Islam would be performed while maintaining the harmony of the local traditions (Said, 2015).

The discussion of the spread of Islam in Indonesia is inseparable with the role of Wali Songo, who are Syekh Maulana Malik Ibrahim, Sunan Ampel, Sunan Bonang, Sunan Gunung Jati, Sunan Kudus, Sunan Giri, Sunan Muria, Sunan Drajat, Sunan Kalijaga. Islam grew rapidly in Java because of their struggle. Their da'wah was based on the principles of tolerance, peacefulness, open-mindedness, and local culture accommodation and adaptation, values, and customs (Kasdi, 2017).

Each of Wali Songo has their unique way in approaching indigenous people of Java to accept Islam. Sunan Bonang, for example, used Gamelan (a traditional musical instrument) to adapt traditional songs to Islam. Sunan Drajad also created melodies for Gamelan, in particular, the Gending Pangkur theme. Sunan Kudus was famous for adopting Wayang Golek, the Indonesian puppets which were usually used for the Sanskrit epics Mahabharata and Ramayana; for incorporating Hindu and Buddhist symbols in architecture 
(Aldyan, 2020; Kasdi et al., 2021). Besides, Sunan Kalijaga used Wayang and music, imposed Baju Takwa, a particular Muslim fashion. Sunan Muria used traditional instruments from the gamelan and an in-depth knowledge of Javanese culture (Fournié, 2019).

Wali Songo's introduction of Islam to people in Java resulted in a hybrid form of Islam where it gradually mixed with adat (customary law), Hinduism, Buddhism, and Javanese mystical practices (Weintraub, 2011). The meet up of Islam and the local treasures made Islam highly multifaceted. When Islam encountered a variant of the local cultures, what immediately happened was a multifarious process of symbiosis that enriched one another (Said, 2015). Hence, there were different variants of Islam: Bugis Islam, Java Islam, Sasak Islam, Malay Islam, Madura Islam, Coastal Islam, Poliwali Islam, Ambon Islam, Padang Islam, Banjar Islam, Bima Islam, and so forth. Such diversity well reflected how Islam always added in a local color as it approached a community.

The process of Islamization in the Nusantara experienced a very complicated and lengthy process which gradually led Islam to be integrated with the traditions, norms, and the indigenous ways of life (Musawar \& Zuhdi, 2019). There was an encounter between the teachings of Islam that had just been brought by Islamic preachers with local traditions united in society individually and collectively (Luthfi, 2016; Purwanto, 2019; Ridwan et al., 2019). It could not be classified as Islamic and local products, yet bequeathed and transmitted from the past to the present (Kholil, 2008).

On the religion of Java, Geertz (1994) divided Javanese Muslims society into three behavioral groups: Abangan, Santri and Priyayi. Muslim Abangan refered to those who still practice rituals syncretised between animist, Hindu, and Muslim tradition. Santri refered to Muslims who practiced a pure form of Islam. While Priyayi, the last group, referred to the minority groups: the Hindu Javanese aristocracy. Such distinction is still used to divide the Indonesian Muslim community between Santri, close to the Muslim association Muhammadiyah (about 50 million members) and Abangan, now regrouped as Nahdlatul Ulama (NU) (about 90 million members). These worshipers cover reformists (influenced by the Middle East and Wahabism) and the more traditionalists (practicing what is called Islam Nusantara) (Hasyim, 2019).

el Harakah Jurnal Budaya Islam Vol. 23 No. 1 Tahun 2021 


\section{Method}

The study was conducted in Sumbermujur village, Candipuro, Lumajang. It was a case study which employed a qualitative approach with primary data collected through interview and participant observation. According to Creswell (1994) qualitative research is the process of comprehending social problems or related to human as a whole, complex, and holistic. Interviews were conducted with community leaders, the head of the village, and villagers. Both interviews and observation were conducted during the event of Grebeg Suro.

\section{Findings and Discussion}

\section{The Ritual of Cow Head Burial}

Burying a cow head was one of the rituals in Grebeg Suro held by people in Lumajang. It was held in the Bamboo Forest area. All villagers and hundred guests gathered. The ritual began with a cow slaughter. The body of the cow will be cooked and consumed by the villagers while the cow head was decorated with a small red and white flag. The cow head is placed facing the sky on a small stretcher, the size of the cow head. The stretcher is made of bamboo designed with a handle to be lifted by the stretcher carrier.

There are four stretchers to be gathered in the ceremony with the mountain of crops and tumpeng. The excavation of the hole is initiated symbolically by the Regent of Lumajang and the Chief of Police. Then, the village head and several elders put the cow head into the hole and fill it with soil.

The ritual is attended by the Lumajang district head, village officials, and all of the community members. Traditional Javanese dance and music are performed during the ritual. People follow the ritual silently. There is also a prayer during the ritual which is a combination of Javanese and Arabic.

Why a cow head? In many societies, a cow is considered to be sacred, holy. A cow is often perceived as a symbol of nurturing, power, and fertility. The cow has been closely associated to the concept of Mother Earth in many cultures. For hundreds of years, for some societies such as Hindu people, cows have been very generous with their life force. As a symbol of nurturing, power, and fertility, a cow has been closely associated with Motherland concept in many cultures. For hundreds of years, cows have been very generous with their life force and have always behaved selflessly that their symbol is married to the concept of provision. The cow totem is connected to the Earth, nature, and reproduction, much like the bull (Britannica, 2021). 
Moreover, according to an Egyptian mythology, a cow is the mother of Sun. It is the symbol of wealth, fertility, and renewal. Hesat is an ancient Egyptian goddess in the form of a cow. Hesat is well-known with her milk called "the beer of Hesat". Another goddess in Egyptian mythology is Hathor. Hathor is worshipped as the Great Mother. She is personified as a young woman. She is responsible to feed the Pharaoh with her milk. She is an emblem of royalty. She is the faith in survival, the spirit of three, the ruler of the sky, and the Queen of the World of death. Because of their maternal auras, "new beginnings" or birth are also associated with cows. They depict the beautiful cycle of life from pregnancy, giving birth, taking care of their offspring, and as a medium for new life. They're also a lunar symbol connected to the feminine side or yin of the Yin-Yang dynamic. They signify a grounding kind of sustenance and abundance and prestige as they have an essential role in the course of living (Britannica, 2021).

In the Hindu tradition, cows are considered to be sacred. Cows are honoured and deeply respected. Cows are seen as a 'caregiver' or maternal figure. Bhoomi is one of Hindu goddess in the form of a cow. She represents the Earth. There is a festival to thank cows for serving farmers for agriculture. This festival is called "Mattupongal", which is one of the four days of the grand Indian festival called the Pongal which is completely focused on thanking every agricultural implement. Most Hindu respect cows for their gentle nature, and cows also represent strength. Hindus who eat meat will avoid eating cow meat (Simoons et al., 1981).

According to Simoons et al. (1981), in the minds of Hindus, the cow is the favored animal of Khrisna. Khrisna is very important to Hindu people since Krishna is the heroic god King. Moreover, one of the pillars of Hindu beliefs in the Ahimsa principle that cows represent. It teaches Hindus not to bring harm onto other living beings. So, the cow's image of gentleness and beings. So, the cow's image of gentleness and being grounded and connected to nature perfectly exemplifies what Ahimsa is all about. Although most Hindus are vegetarian, the cow milk is still used for dairy products, playing a considerable part in their diet (Britannica, 2021).

In Islam, cows are considered to be like other animals. Cows have no particular place. However, it is used to name one of the Surah in Al-Qur'an, Al Baqarah (-the Cow). This tittle of the surah refers to an argument between Moses and the Israelites over a cow they should sacrifice to make known the

el Harakah Jurnal Budaya Islam Vol. 23 No. 1 Tahun 2021 
murder of a slain man. It is the longest of all surah, numbering 286 ayah or verses.

\section{Cow Head Burial and the Concept of Salam}

The ritual of planting cow head was considered to be the form of salam (Slametan). Cow head is symbolized as a gratitude to God. The community in Sumbermujur believed that the ritual of planting will bring safety to the community. From the ritual of planting the cow's head, the surrounding community assumed that they would be safe from all dangers. According to the elders of Sumbermujur Village, by carrying out this tradition, their lives will be better and avoid life disasters. Sumbermujur village community leaders also mentioned that the slamet means the sustainability of water sources and the assurance of agricultural land protected from disasters.

The concept of survival from the Javanese perspective covers all respective areas that the leaders in Sumbermujur village also share. Therefore, slamet has both world and spiritual dimensions. The daily life of Sumbermujur community is expected to run well and increase better yield, and so on. The concept of slamet may be the same for all Javanese tribes, both the mataraman version (the southern coastal version) and the horseshoe version. This division of two regions shows quite striking differences in characteristics, such as only coastal people and inland people.

The word slamet is significant to people of Java. It is a Javanese word, and most probably derived from Arabic "salam", which means well being, peace, safety, health, goodness and in essence it refers to the state of stasis or simply 'nothing happens' to one or people (Geertz, 1991). Slamet is the main goal, and it is the ideal condition always expected in life. Being slamet implies that one is safe, in the sense that people can avoid difficulties or troubles from natural or supernatural condition. To be slamet is to have nothing happens or troubles (ga ana apa apa). The utmost ideal state in life and slametan ceremony is performed and maintained as the fear of possible misfortune which drives them and overpowers their action to hold the slametan ritual. The purpose of slametan is not to quest for joy, financial richness, best healthiness, but simply to prevent from unwanted events, from things that will make them unwell physically or mentally, from a condition which causes them to be ill or sad. 


\section{The Acculturation of Islamic Values and Local Culture (Cow Head Burial Ritual)}

The ritual conducted every Suro month by burying a cow head is a characteristic of the people in the Lumajang bamboo forest. It is an indigenous behavior, which covers contextual meanings, values, and beliefs in the family, social, cultural, and ecological areas (Kim, 2000). The ritual of burying the cow head is assumed to generate safety from all dangers. The assumption of slamet or safety by planting a cow head raises the researchers' curiosity to get reviews and explanations from the perpetrators about the concept.

Javanese people had gained many religious ideas: animistic, HinduBuddhist teachings-practices and combining magic, mysticism, and awe of powerful souls, spirit cults, and the worship of holy places (Hakam, 2017). Javanese culture and religion comprise significant variation of beliefs, concepts, views, and values, such as the belief in God, in prophet Muhammad, in other prophets, in saints, the cosmogonical concept of creation, and the cosmological view of nature, and the world, eschatology, the belief in deities, the concept of death and the afterlife, in ancestor spirits, in guardian spirits, in ghosts, spooks and giants, and the concept of magical power (Koenjtaraningrat, 1985).

After the advent of Islam in Java, the changes in their belief are not leading to becoming homogenous Javanese Muslims but instead allowing them to be diverse in interpreting Islam and its teaching and their previous or existing beliefs. The non-homogeneity of Javanese Muslims can be construed either hierarchically or through socio-cultural backgrounds. As Geertz (1994) proposed, Javanese people are categorised into three; abangan, santri, and priyayi. The priyayi were originally the descendants of aristocrats or royal family in ancient Javanese kingdoms, and they became the government officials under the colony of Dutch. These elite people hold their traditions of respecting court etiquette, complex sense of arts including drama, music, dance, HinduBuddhist mysticism, and linguistic aspects, such as poetry and use of different language levels and addressing between the social ranks as the subordinates can speak the same language.

In Javanese culture, cows are sacred and good animals. Their existence is significant in everyday life. They are food sources, partners in working and cultivating agriculture. "... burying a cow head symbolizes purity in intention and toughness in the work ethic because cows are sacred animals as well as friends in earning fortune in the source of luck society..." (Interview 3, 19). The ritual of burying a cow head is connected with a symbolic meaning that it is crucial 
to have a holy intention that is on the head, strengthened by the heart and manifested in daily behavior. Working hard is not enough. It needs a holy intention because an impure intention will lead people to greed and unkind behavior. Burying cows reminds people that it is necessary to organize their choices in the next year so that life will be better, and blessings are continuously granted. The preservation of this culture shows that Sumbermujur community emphasizes goodness, behaving based on the right intention, which is seeking God Almighty blessing.

According to Ki Narto Sabdo, a culture is an air of beauty. There is a tendency for Islam to be modified with Javanese culture (in Amin, 2000). It has generated various new products, one of which is the interrelation of Javanese and Islamic cultural values in the ritual aspect. In Islam, there are religious teachings formed in ritual worship activities. This ritual in Islam refers to the pillars of Islam that Muslim must do, in which there found a prayer that always asks Allah to be pleased with Him. It is the same as the purpose of rituals carried out by the Javanese people, namely to seek for blessings, or what is known as ngalap barokah, which means wishing for safety, happiness, and mercy.

The ritual or ceremony contains something mystical, holy, and sacred (Syam, 2005). The essence of worship in the Javanese religion is the worship of ancestors (Geertz, 1999). It manifests itself in mystical and immortal attitudes. Even though they worship the spirit, in essence, they still focus on God Almighty (Endraswara, 2006).

Local wisdom and local genius express religious teachings through local culture and traditions (Hidayat, 2012). The ritual or ceremony was initially an antidote to bad things that could harm humans. It is done by giving offerings to occult stuff, hoping that life will be safe (Purwadi, 2007). Slamet is a concept for the benefit of living life. Not just a dimension of being healthy, safe, and prosperous but the gift to other people and other creatures. And this is reflected in the thanksgiving by the people of Sumbermujur Village, "... apart from burying the head of the cow, we also prepare offerings or alms from agricultural yields from our community. This shows our gratitude for the gifts that God has given. Technically, both the head of the cow and the offering of yields to be prepared together, donated together, and also enjoyed together ..." (Interview 3, 47)

Veth (in Kholil, 2008) argues that not all of the adherents of Islam convert purely. According to Veth, Islam adherents are grouped into four groups: Islamists who still hold a mixture of Brahma and Buddhist beliefs; 
Islamists who have magical ideas and dualism; Islamists who have animism; and Islam adherents who carry out Islamic teachings purely. Javanese belong to the first three groups, and until now, the Javanese teachings of Kejawen are still widely adhered to by Muslims who continued the local tradition. Local tradition is never static or stopped but it develops, so the attitude of Islam in dealing with culture can be divided into three: (1) accepting and developing a culture, following Islamic principles for the glory of human life; (2) rejecting traditions and cultural elements that are contrary to Islamic principles; (3) leaving it like how to dress (Zuhdi, 2019).

\section{Conclusion}

Javanese culture was historically dynamism-animism, Hindu, Buddhist, and Islam acculturated. Furthermore, this acculturation creates a unique and rich diversity, which ultimately forms an independent Javanese culture. Grebeg Suro is an example of how the Islamic values and local culture are acculturated. It is not only a cultural event, but it also contains religious values. The study results describe the meaning of slamet from the ritual performers of cow head planting in the bamboo forest of Sumbermujur Lumajang in terms of an indigenous psychology approach. Slamet is a concept of the usefulness of life. It's not just a dimension of being healthy, safe, and prosperous, but benefit to other people and creatures. It is reflected in the thanksgiving by the people of Sumbermujur Village. The community leaders of Sumbermujur also states that slamet means preservation of water sources and assurance that agricultural land was protected from disasters. Besides, it has both worldly and spiritual dimensions. The life of people in Sumbermujur is expected to run well and can increase in quality and quantity. Psychologically, the ritual of burying a cow head leads people of Sumbermujur to feel peace as a gratitude and belief in "slamet". This research is expected to contribute in calling people for preserving local culture and Islamic values within the rituals. It is limited to the exploration of the Islamic values behind the ritual of a cow head burial in Grebeg Suro ceremony. Further researches might analyze the ritual from the historical background. Besides, an analysis on the other Grebeg Suro rituals, such as Gunungan, Tumpengan, Japa Mantra, Larungan, and the dancing ritual, could be a great option to conduct.

el Harakah Jurnal Budaya Islam Vol. 23 No. 1 Tahun 2021 


\section{References}

Aldyan, R. A. (2020). The Commodification of Religious Tourism in the Tomb of Sunan Kudus. Cultural Tourism Research, 2(7), 32-47.

Amin, D. (2000). Islam dan Kebudayaan Jawa. Yogyakarta: Gama Media.

Berry, J. W. (2005). Acculturation: Living successfully in two cultures. International journal of intercultural relations, 29(6), 697-712.

Britannica https://www.britannica.com/

Creswell, J. W. (1994). Research Design Qualitative and Quantitative Approaches. Sage Publications.

Endraswara, S. (2006). Mistik Kejawen. Yogyakarta:Narasi.

Fournié, P. (2019) Rediscovering the Walisongo, Indonesia: A potential new destination for international pilgrimage, International Journal of Religious Tourism and Pilgrimage 7(4). https://doi.org/10.21427/g00f-qd76

Geertz, C. (1994). The Religion of Java. Chicago: The University of Chicago Press.

Geertz, C. (1999). After The Fact: Dua Negeri, Empat Dasawarsa, Satu Antropolog, transl. Landung Simatupang \&Hairus Salim: After The Fact: Two Countries, Four Decades, One Antropologits. Yogyakarta: LKiS.

Hanif, M., \& Zulianti, Z. (2012). Simbolisme Grebeg Suro di Kabupaten Ponorogo. AGASTYA: Jurnal Sejarah dan Pembelajarannya, 2(1).

Hidayat, K. (2012). Agama Punya 1000 Nyawa. Jakarta: Noura Books.

Kasdi, A. (2017). The Role of Wali Songo in Developing Islam Nusantara Civilization. ADDIN, 11(1), pp. 1-26.

Kasdi, A., Nashirudin, M., Farida, U., \& Praatmana, N. D. (2021). Potential of Kudus as a New International Pilgrimage Destination in Indonesia: Halal Tourism Optimising Local Wisdom. International Journal of Religious Tourism and Pilgrimage, 9(1), 9.

Kholil, A. (2008). Islam Jawa, Sufisme dalam Etika dan Tradisi Jawa. UIN Maliki Press. 
Kim, U. (2000). Indigenous, Cultural, and Cross Cultural Psychology: A theoretical, conceptual, and epistemological analysis. Asian Journal of Social Psychology 3, 265-287.

Koentjaraningrat. (1985). Javanese culture. Oxford University Press.

Lestari, E. S. (2011). Nilai-nilai kearifan lokal dalam Grebeg Suro di Kabupaten Ponorogo (Doctoral dissertation, Universitas Negeri Malang).

Luthfi, K. M. (2016). Islam Nusantara: Relasi Islam dan Budaya Lokal. SHAHIH: Journal of Islamicate Multidisciplinary, 1(1), 1-12.

Purwadi (2007). Upacara Tradisional Jawa, Menggali Untaian Kearifan Lokal. Yogyakarta: Pustaka Pelajar.

Purwanto, M. R. (2019). Thought Of Nusantara Moslem Scholars: Fiqh Concepts of Syeikharsyad Al-Banjari In Sabilalmuhtadin. Akademika: Jurnal Pemikiran Islam, 24(1), 187-212.

Ridwan, B., Syahputra, I., Tarigan, A. A., Siregar, F. A., \& Nofialdi, N. (2019). Islam Nusantara, ulemas, and social media: understanding the pros and cons of Islam Nusantara among ulemas of West Sumatera. Indonesian Journal of Islam and Muslim Societies, 9(2).

Said, M. (2015). A Study on the Acculturation of Islam and Local Culture Bungamale as a Local Culture of South Sulawesi. JICSA (Journal of Islamic Civilization in Southeast Asia), 4(2).

Sumbulah, U. (2012). Islam Jawa dan Akulturasi Budaya: Karakteristik, Variasi dan Ketaatan Ekspresif. el Harakah, 14(1).

Syam, N. (2005). Islam Pesisir. Yogyakarta: LkiS Pelangi Aksara.

Weintraub, A. N. (Ed.). (2011). Islam and popular culture in Indonesia and Malaysia (Vol. 24). Routledge.

Zuhdi, M. H. (2019). Islam Nusantara That Is Sacred and Ignored (Thinking Analysis of Sasak Lombok Ulama). Journal of Legal, Ethical and Regulatory Issues, 22(3), 1-5.

Hakam, A. (2017). Communal Feast Slametan: Belief System, Ritual, and the Ideal of Javanese Society. Hayula: Indonesian Journal of Multidisciplinary Islamic Studies, 1(1), 97-111. https://doi.org/10.21009/hayula.001.1.06

el Harakah Jurnal Budaya Islam Vol. 23 No. 1 Tahun 2021 
Hasyim, S. (2019). Religious pluralism revisited: Discursive patterns of the ulama fatwa in Indonesia and Malaysia. Studia Islamika 26(3), 475-509. https://doi.org/10.36712/sdi.v26i3.10623

Jalais, A. (2014). Bengali 'Bihari' Muharram: The Identitarian Trajectories of a Community. South Asia Chronicle, 4, 69-93.

Kurniawan, S. (2019). Komunikasi Ritual Suroan pada Masyarakat Suku Jawa di Kota Bengkulu. Jurnal Ilmiah Syi'ar. https://doi.org/10.29300/syr. v19i2.2467

Musawar, \& Zuhdi, M. H. (2019). Islam Nusantara that is sacred and ignored (thinking analysis of Sasak Lombok Ulama). Journal of Legal, Ethical and Regulatory Issues 22(3), 1-5.

Nurbaiti (2020). Islamic Education: The Main Path of Islamization in Southeast Asia. Jurnal Pendidikan Islam 26(2), 303-316. https://doi.org/10.14421/ jpi.2019.82.345-374

Said, M. (2015). A study on the acculturation of Islam and local culture. Journal of Islamic Civilization in Southeast Asia 4(2).

Siburian, A. L. M., \& Malau, W. (2018). Tradisi Ritual Bulan Suro pada Masyarakat Jawa di Desa Sambirejo Timur Percut Sei Tuan. Gondang: Jurnal Seni Dan Budaya. https://doi.org/10.24114/gondang.v2i1.9764

Simoons, F., Simoons, F., \& Lodrick, D. (1981). Background to Understanding the Cattle Situation of India: The Sacred Cow Concept in Hindu Religion and Folk Culture. Zeitschrift Für Ethnologie, 106(1/2), 121-137. 